\title{
Electrophysiological response to local steroid injection in carpal tunnel syndrome
}

\author{
Mohammed I. S. Sabaawi ${ }^{a}$, Mahmood A. Aljumaily ${ }^{b}$, Miss Muna M. Ahmad ${ }^{c}$ \\ From the a Department of Physiology, ${ }^{b}$ Department of Surgery, ${ }^{\mathrm{c}}$ Department of Community Medicine, College of Medicine, \\ University of Mosul, Mosul, Iraq. Correspondence: Mohammed I. S. Sabaawi ${ }^{\mathrm{a}}$. me_alsabawy@yahoo.com. \\ (Ann Coll Med Mosul 2013; 39 (2): 118-122). \\ Received: $3^{\text {rd }}$ Jun. 2012; Accepted: $19^{\text {th }}$ May 2013.
}

\section{ABSTRACT}

Background: Carpal tunnel syndrome (CTS) is a common entrapment neuropathy. Local steroid injections are used for its treatment, which is usually associated with improvement in different electrophysiologic parameters of the median nerve. However, evidence for its efficacy has not been established in our community.

Objective: The aim of this study is to evaluate the changes in electrophysiological parameters after local steroid injection for mild and moderate idiopathic CTS.

Material and methods: The study is a prospective clinical trial assessing the electrophysiological parameters following local steroid injection (Depomedrol-80 mg methylprednisolone acetate) in the treatment of mild and moderate idiopathic CTS. The study was carried out in Mosul Teaching Hospitals during a period from December 2010 to December 2011. The total number of patients was 54 (46 females and 8 males), their mean age was $36.13 \pm 9.32$ years. Patients with idiopathic CTS were included after clinical confirmation of diagnosis electro-physiologically at preinjection, and electro physiological evaluation repeated 1 and 6 months after local steroid injection.

Results: All electrophysiological parameters showed significant improvement $(P$ value is $<0.05)$ one month after injection except sensory nerve action potential. All median nerve electrophysiological parameters in 6 months post injection showed no significant changes except, compound motor action potential, motor nerve conduction velocity, and sensory nerve action potential which showed significant deterioration $(P$ value is < 0.05 ). All electrophysiological parameters showed significant deterioration ( $P$ value is $<0.05$ ) in comparing results of one month and 6 months after injection.

Conclusion: Local steroid injection for CTS provides transient improvement in electrophysiological parameters while causes deterioration in these parameters 6 months after injection.

Keywords: Carpal tunnel syndrome, steroid injection electrophysiology.

$$
\begin{aligned}
& \text { الإستجابة الكهروفسيولوجية للزرق الموضعي بالسترويد في متلازمة النفق الرسغي }
\end{aligned}
$$

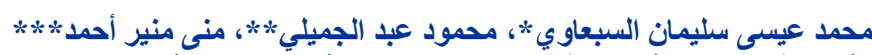

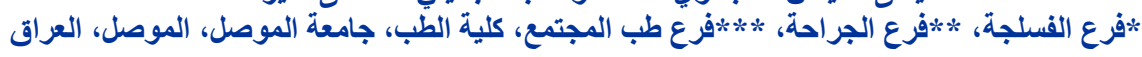

الخلفية: متلازمة النفق الرسغي حالة شائعة و الزرق الموضعي بالستيرويد يستخدم في علاجها وعادة ما يرتبط بتحسن في

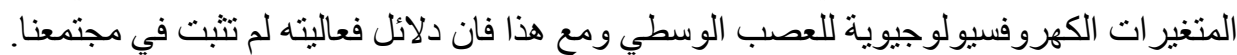

الأهداف: تهدف الدراسة لتقييم التغيرات الكهروفسيولوجية اللغية بعد الزرق الموضعي للستيرويدات في متلازمة النفق الرسني الخفيفة و المتوسطة. المواد وطريقة العمل: أجريت هذه الدر اسة السريرية لتقييم المتغيرات الكهروفسيولوجية بعد زرق • م ملغم من المثيل بردنزولون

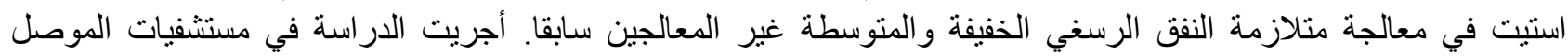

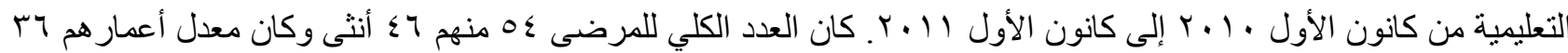

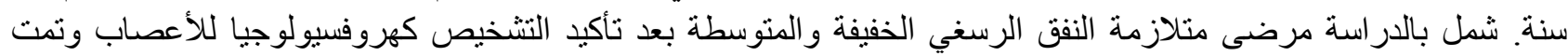

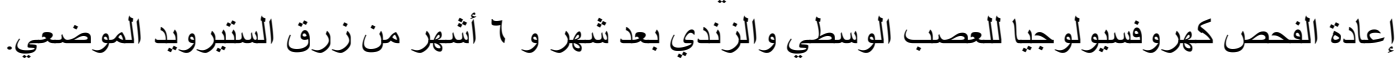




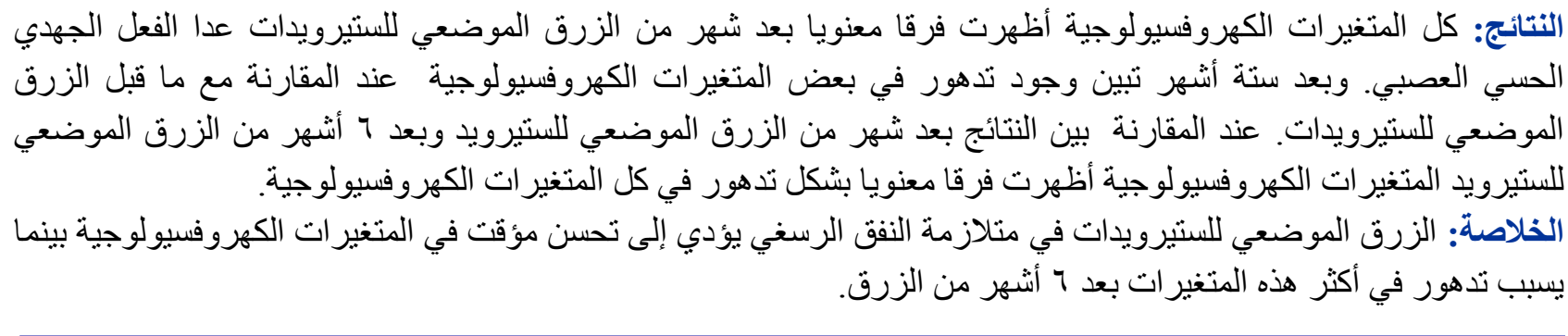

\section{INTRODUCTION}

C arpal tunnel syndrome CTS results from entrapment and compression of the median nerve in the wrist, it is the most common variety of the entrapment neuropathies. ${ }^{1}$ The common symptoms are tingling, numbness, and pain in the hand that may radiate to the forearm or shoulder. ${ }^{1-3}$ The non-surgical treatment options of CTS include splinting, steroids, activity modification, and others. $^{1-4}$ Corticosteriod injections are frequently used to treat CTS, and are considered to be both safe and effective for short-term. ${ }^{1-6}$ The traditional approach is to use a trial of local steroid injection in patients with mild and moderate or transient $\mathrm{CTS}^{7,8}$ Most complications of steroid injection in CTS are mild. ${ }^{8}$ Electrophysiological measurements are the gold standard diagnostic tests and are integral components in the diagnosis of CTS and provide an objective measurement of the function of the studied nerve. ${ }^{3,6}$ The electrophysiologic parameters may improve over the short term after steroid injection, and these improvements decrease as the severity of CTS increases. ${ }^{7,8}$

By reviewing the available literatures, there were no registered studies on effect of local steroid injection in treatment of idiopathic CTS in our community. The aim of this study is to evaluate the changes in electrophysiological parameters one month and six months after local steroid (Depomedrol- $80 \mathrm{mg}$ methylprednisolone acetate) injection for mild and moderate idiopathic CTS.

\section{MATERIAL AND METHODS}

This study was approved by the scientific committee at the College of Medicine, University of Mosul. Formal consent was taken from patients after explanations of the trial to them. The patients were collected from the Rheumatology, Orthopedic, and Neurophysiology outpatient clinics in Mosul Teaching Hospitals between December 2010 and December 2011. The total number of patients with mild and moderate CTS included was 54 (46 females and 8 males), unilateral in 41 patients (37 right and 4 left), and bilateral in 13 patients, their mean age was $36.13 \pm 9.32$ years (ranged between 20 and 55 years).

Inclusion criteria were clinical diagnosis of mild to moderate primary idiopathic CTS confirmed and evaluated electro-physiologically, and symptom severity of such magnitude that the patient is willing the steroid injection. ${ }^{9,10}$ In patients with bilateral symptoms the most symptomatic hand or dominant hand (as reported by the patient) will be included.

The patients with history of previous steroid injection for CTS in the same wrist, inflammatory joint disease, presence of contraindications for corticosteroid injection, polyneuropathy, pregnancy, fractures of the affected wrist in the previous year, previous surgery for CTS in the affected hand, and severe type electrophysiologically were excluded from the study. Eleven patients were excluded because they didn't complete electrophysiological evaluations.

The mixture of $2 \mathrm{ml} 80 \mathrm{mg}$ Methylprednisolone acetate (Depomedrol $40 \mathrm{mg} / \mathrm{ml}$ ) $+1 \quad \mathrm{ml} 10$ Xylocaine $(10 \mathrm{mg} / \mathrm{ml})$ was injected just to the ulnar side of the palmaris longus tendon, proximal to the wrist crease. The needle was aimed toward the carpal tunnel at a 10- to 20-degree angle of entry. If there were no parasthesia during insertion of the needle, the mixture was injected. ${ }^{9}$ After injection, patients are instructed to use their hands normally as tolerated; no instructions are given regarding specific activity modifications or splint use.

At preinjection and after one and six months electrophysiological study was performed according to the guidelines of the American Association of Neuromuscular and Electrodiagnostic Medicine for CTS for median and ulnar nerves of the injected hand. ${ }^{11}$ Electrophysiological parameters were measured by a machine (system 98- MyoQuik micromed USA). The procedure was 
explained for the patients, the skin was prepared before the application of electrodes. The active electrode is placed on the muscle belly for motor study and the reference electrode was placed on the tendon of the same muscle, while the grounding electrode was placed on the wrist between the stimulator and active parameters electrode. The sensory parameters were measured by placing active electrode at the base of the index and the reference electrode was placed at the tip of the index, while the stimulator electrode was placed at the wrist. Electrophysiological parameters included distal motor latency (DML), compound motor action potential (CMAP), motor nerve conduction velocity (MNCV), F-Wave minimal latency (FWML), distal sensory latency (DSL), sensory nerve action potential (SNAP), and sensory nerve conduction velocity (SNCV). The ulnar nerve was studied in the same way. The diagnostic criteria for CTS include: distal motor latency of more than 4.3 $\mathrm{m} / \mathrm{sec}$, motor or sensory nerve conduction of less than $45 \mathrm{~m} / \mathrm{sec}$, and more than $0.5 \mathrm{~m} / \mathrm{sec}$ latency difference in comparative test between median and ulnar nerves. ${ }^{10,11}$ The patients were grouped as having mild, moderate and severe CTS. ${ }^{11}$

Statistical analysis: We used the SPSS package 11 for Windows XP. The mean, standard deviation (SD) was calculated in patients for each parameter. The student ( $t$ ) test was used to calculate the differences between the two means. ANOVA Test and Post Hoc (Duncan) test were used in analysis of results. The $p$ value was considered as significant if it was less than 0.05 .

\section{RESULTS}

The total number of patients was 54 (females to males ratio 5.75:1), 41 patients with unilateral lesion, all were dominant hand (37 right and 4 left), and 13 patients with bilateral lesions, the total number of hands for study was 67 (Dominant hand involvement was present in $80.6 \%$ ). The mean age was $36.13 \pm 9.32$ years (ranged between 20 and 55 years), most of patients were between $30 \& 50$ years. The severity was mild in $28(52 \%)$ and moderate in $26(48 \%)$. Duration of symptoms was of more than 3 months in 34 patients $(63 \%)$ and less than 3 months in 20 patients (37\%). The body mass index of patients was normal in 6 patients (11.1\%), overweight in 45 (83.3\%), and obese in 3 patients $(5.6 \%)$. None of the patients experienced any significant complications or pain exacerbation after injection or electrophysiological abnormalities.

\section{(Table 1)}

All median nerve electrophysiological parameters (DML, CMAP, MNCV, FWML, DSL, and SNCV), in comparing preinjection and one month post injection showed significant changes ( $P$ value is < 0.05 ) in pattern of improvement in functions ( $P$ value is $<0.05$ ) except SNAP, which showed no significant changes. All median nerve electrophysiological parameters in comparing preinjection and 6 months post injection showed no significant changes except, CAMP, MNCV, and SNCV (showed deterioration). All median nerve showed significant changes ( $P$ value is $<0.05$ ) in form of deterioration in electrophysiological parameters in comparing one month and 6 months post injection nerve functions. The electrophysiological parameters for ulnar nerve in the same hand of CTS in preinjection and post injection studies showed no significant changes ( $P$ value is $>0.05$ ). (Table 2).

Table 1. Criteria of patient's age, gender, severity of CTS, site of affection, duration of symptoms, patient's body mass index.

\begin{tabular}{|c|c|}
\hline Parameters & $\begin{array}{c}\text { Number of patients and } \\
\text { percentage (total number of } \\
\text { patients are } 54 \text { ) }\end{array}$ \\
\hline \multicolumn{2}{|l|}{ Age } \\
\hline $20-29$ & $13(24.1)$ \\
\hline $30-39$ & 18 (33.3) \\
\hline $40-49$ & $20(37.0)$ \\
\hline$>50$ & $3(5.6)$ \\
\hline \multicolumn{2}{|l|}{ Gender } \\
\hline Male & $8(14.8)$ \\
\hline Female & 46 (85.2) \\
\hline \multicolumn{2}{|l|}{ Severity } \\
\hline Mild CTS & 28 (51.9) \\
\hline Moderate CTS & $26(48.1)$ \\
\hline \multicolumn{2}{|l|}{ Site } \\
\hline Right & 37 (68.5) \\
\hline Left & $4(7.4)$ \\
\hline Bilateral & $13(24.1)$ \\
\hline \multicolumn{2}{|l|}{ Duration (months) } \\
\hline$\leq 3$ & $20(37.0)$ \\
\hline$>3$ & $34(63.0)$ \\
\hline \multicolumn{2}{|l|}{ BMI } \\
\hline$\leq 25$ & $6(11.1)$ \\
\hline $26-30$ & 45 (83.3) \\
\hline$>30$ & $3(5.6)$ \\
\hline
\end{tabular}


Table 2. The median nerve electrophysiological parameters in preinjection and post injection.

\begin{tabular}{|c|c|c|c|c|}
\hline \multirow{2}{*}{$\begin{array}{l}\text { Parameters in median nerve in } \\
\text { preinjection and post injection } \\
\text { study }\end{array}$} & Pre injection & $\begin{array}{c}\text { One month after } \\
\text { injection }\end{array}$ & $\begin{array}{c}\text { Six months after } \\
\text { injection }\end{array}$ & \multirow[t]{2}{*}{$\mathbf{P}^{*}$-value } \\
\hline & Mean \pm SD & Mean \pm SD & Mean \pm SD & \\
\hline Distal motor latency (DML) (ms) & $\begin{array}{c}5.55 \underset{(a)^{* *}}{ \pm} \\
\end{array}$ & $\begin{array}{l}4.52 \pm 1.32 \\
\text { (b) }\end{array}$ & $\begin{array}{l}5.49 \pm 1.03 \\
\text { (ac) }\end{array}$ & 0.000 \\
\hline $\begin{array}{l}\text { Compound motor action potential } \\
\text { (CMAP) (mv) }\end{array}$ & $\begin{array}{c}8.24 \pm 2.60 \\
\text { (a) }\end{array}$ & $\begin{array}{l}11.91 \pm 4.35 \\
\text { (b) }\end{array}$ & $\begin{array}{c}6.80 \pm 1.55 \\
\text { (c) }\end{array}$ & 0.000 \\
\hline $\begin{array}{l}\text { Nerve conduction velocity- motor } \\
\text { (MNCV) (mls). }\end{array}$ & $\begin{array}{c}41.08 \pm 5.42 \\
\text { (a) }\end{array}$ & $\begin{array}{c}46.44 \pm 7.53 \\
\text { (b) }\end{array}$ & $\begin{array}{c}38.65 \pm 3.96 \\
\text { (c) }\end{array}$ & 0.000 \\
\hline $\begin{array}{l}\text { F-Wave minimal latency (FWML) } \\
\text { (ms) }\end{array}$ & $\begin{array}{l}29.59 \pm 3.14 \\
\text { (a) }\end{array}$ & $\begin{array}{l}26.92 \pm 3.51 \\
\text { (b) }\end{array}$ & $\begin{array}{l}29.40 \pm 2.25 \\
(\mathrm{ac})\end{array}$ & 0.000 \\
\hline Distal sensory latency (DSL)(ms) & $\begin{array}{c}5.44 \pm 1.23 \\
\text { (a) }\end{array}$ & $4.48 \pm 1.30$ & $\begin{array}{c}5.51 \pm 0.95 \\
(\mathrm{ac})\end{array}$ & 0.000 \\
\hline $\begin{array}{l}\text { Sensory nerve action potential } \\
(\text { SNAP }) \backslash(\mu \mathrm{v}) \text {. }\end{array}$ & $\begin{array}{c}545.6 \pm 205.8 \\
(a b c)\end{array}$ & $\begin{array}{c}604.0 \pm 218.8 \\
\text { (b) }\end{array}$ & $\begin{array}{c}519.8 \pm 186.2 \\
\text { (c) }\end{array}$ & 0.093 \\
\hline $\begin{array}{l}\text { Nerve conduction velocity (sensory) } \\
\text { (SNCV). (mls). }\end{array}$ & $\begin{array}{c}38.98 \pm 4.62 \\
(\mathrm{a})\end{array}$ & $\begin{array}{c}47.09 \pm 7.12 \\
\text { (b) }\end{array}$ & $\begin{array}{c}37.49 \pm 3.80 \\
(\mathrm{ac})\end{array}$ & 0.000 \\
\hline
\end{tabular}

* ANOVA Test was used

** Post Hoc test (Duncan)

Single litters mean that there are significant differences between variant.

Combined litters mean that there is no significant difference between variances.

\section{DISCUSSION}

In our study the demographic and clinical criteria of patients were similar to other studies except the mean age at presentation which was 36.13 years. Other studies reported higher mean age, ${ }^{1,3,5,8,12}$ which might be explained by early child bearing and overwork of housewives in our community. Electrophysiological testing remains an essential technique for quantifying median nerve function in CTS due to its inherent reliability, reproducibility, and objectivity. ${ }^{3,13}$ According to the findings after steroid injection, the electrophysiological parameters of median nerve (sensory and motor) improved one month after injection except SNAP (sensory nerve action potential), which showed no significant changes. This might be explained by the fact that the sensory component of the median nerve is affected much earlier than the motor component and in early stages of CTS. ${ }^{3,14,15}$ It seemed that the local steroid injection could lead to a transient improvement in electrophysiological parameters one month after injection by the antiinflammatory and anti-edema effects of the corticosteroid or by inhibiting the spontaneous discharge ability of excitable cells. ${ }^{16,17}$ No special complication occurred in our patients following steroid injection. The improvement of electrophysiological parameters even transient, supports the results of other researchers on effectiveness of steroid injection therapy in CTS one month after injection. ${ }^{15,17-19}$ The patients with mild and moderate CTS can be managed with local injection of steroids but its effect is transient and still controversial. ${ }^{3,17,20}$

Electrophysiological parameters of median nerve six months after local steroid injection showed no significant changes in DML, FWML, and DSL, when compared with results of preinjection, while CAMP, MNCV, and SNCV showed significant deterioration. This indicates that there was some deterioration 6 months after injection despite the transient improvement. This pattern was also noticed by other investigators. ${ }^{13,15,16}$

All electrophysiological parameters of median nerve six months after local steroid injection showed significant deterioration in comparison with the results of one month after injection. Our finding is in the direction of others from Singapore which showed partial worsening of electrophysiological parameters 6 months after steroid injection in mild and moderate CTS. ${ }^{12}$ Many studies failed to demonstrate significant electrophysiological parameters improvement beyond one month and the relapse or worsening of changes is possible. ${ }^{12,16,22}$ However, our results differ from those of others, who found that a single steroid injection to the carpal tunnel may result in long term improvement. ${ }^{3,6,14,23,24}$

We could not find significant changes in electrophysiological parameters in ulnar nerve, which indicates that, there was no systemic deterioration in nerves function and there was no generalized effect of local steroid injection on ulnar nerve of the same hand in post injection follow- 
ups. Comparative tests of electrophysiological parameters between the median and the ulnar nerves in the same hand are well documented in the literatures. ${ }^{9-11,13,25}$

We conclude that steroid injection into the carpal tunnel causes temporary improvement one month after injection and causes significant deterioration 6 months later. Steroid injection in CTS should be used with caution, to prevent deterioration of median nerve function.

\section{REFERENCE}

1. Carlson $\mathrm{H}$, Colbert A, Frydl J, Arnall E, Elliot M, Carlson N. Current options for nonsurgical management of carpal tunnel syndrome. Int J Clin Rheumtol. 2010; 5(1): 129-142.

2. Korthals-de Bos IB, Gerritsen AA, van Tulder MW, et al. Surgery is more cost-effective than splinting Netherlands: results of an economic evaluation alongside a randomized controlled trial. BMC Musculoskelet. Disord. 2006;7:86.

3. Aroori S, Spence R J. Carpal tunnel syndrome. Ulster Med J 2008; 77(1): 6-17.

4. Shi $Q$, MacDermid J C. Is surgical intervention more effective than non-surgical treatment for carpal tunnel syndrome? a systematic review. J Orthop Surg Res 2011; 6: 17.

5. Agarwal V, Singh R, Sachdev A, Shekhar S, Goel D. A prospective study of the long-term efficacy of local methyl prednisolone acetate injection in the management of mild carpal tunnel syndrome. Rheumatology 2005; 44(5):647-50.

6. Karsidag S, Sahin S, Ayalp S. Long term and frequent electrophysiological observation in carpal tunnel syndrome. Eura. Medicophys. 2007;43:327-332.

7. Lee JH, An JH, Lee SH, Hwang EY. Effectiveness of steroid injection in treating patients with moderate and severe degree of carpal tunnel syndrome measured by clinical and electrodiagnostic assessment. Clin. J. Pain. 2009;25:111-115.

8. Flondell M, Hofer M, Björk J, Isam Atroshi I. Local steroid injection for moderately severe idiopathic carpal tunnel syndrome: Protocol of a randomized double-blind placebo-controlled trial. BMC Musculoskelet Disord 2010; 11: 76.

9. Katz JN, Simmons BP. Clinical practice. Carpal tunnel syndrome. N Engl J Med. 2002;346:1807-1812.

10. Werner RA, Andary M. Carpal tunnel syndrome: pathophysiology and clinical neurophysiology. Clin Neurophysiol 2002;113 (9|):1373-81.

11. Jablecki CK, Andary MT, So YT, Wilkins DE, Williams FH. American Academy of Electro diagnostic, Medicine Quality Assurance Committee. Literature review of the usefulness of the nerve conduction studies and electromyography for evaluation of patients with carpal tunnel syndrome. Muscle Nerve 1993; 6: 1392 1414.
12. Tay LB, Urkude R, Verma KK. Clinical profile, electrodiagnosis and outcome in patients with carpal tunnel syndrome: a Singapore perspective. Singapore Med J 2006; 47(12): 1049-52.

13. Aygül R, Ulvi H, Kotan D, Kuyucu M, Demi R. Sensitivities of conventional and new electrophysiological techniques in carpal tunnel syndrome and their relationship to body mass index. $J$ Brachial Plex Peripher Nerve Inj. 2009; 4: 12.

14. Ayhan-Ardiç FF, Erdem HR. Long-term clinical and electrophysiological results of local steroid injection in patients with carpal tunnel syndrome. Funct Neurol. 2000 Jul-Sep;15(3):157-65.

15. Hagebeuk EE, de Weerd AW. Clinical and electrophysiological follow-up after local steroid injection in the carpal tunnel syndrome. Clin Neurophysiol. 2004 Jun;115(6):1464-8.

16. Milani $P$, Mondelli $M$, Ginanneschi $F$, Mazzocchio R, Rossi A. Progesterone - new therapy in mild carpal tunnel syndrome? Study design of a randomized clinical trial for local therapy. J Brachial Plex Peripher Nerve Inj. 2010; 5: 11.

17. Karadaş O, Tok F, Ulaş UH, Odabaşi ZThe effectiveness of triamcinolone acetonide vs. procaine hydrochloride injection in the management of carpal tunnel syndrome: a double-blind randomized clinical trial. Am J Phys Med Rehabil 2011 Apr;90(4):287-92.

18. Martin B I, Levenson L M, Hollingworth W, et al. Randomized clinical trial of surgery versus conservative therapy for carpal tunnel syndrome BMC Musculoskelet Disord. 2005; 6: 2.

19. Moghtaderi A R, Moghtaderi N, Loghmani A. Evaluating the effectiveness of local dexamethasone injection in pregnant women with carpal tunnel syndrome. J Res Med Sci 2011 May; 16(5): 687-690.

20. Visser LH, Ngo Q, Groeneweg SJ, Brekelmans G. Long term effect of local corticosteroid injection for carpal tunnel syndrome: A relation with electrodiagnostic severity. Clin Neurophysiol. 2012; 123: 838-41.

21. Burke $F D$, Bradley $M J$, Sinha $S$, Wilgis E F S, Dubin $\mathrm{N} \mathrm{H}$. Primary care management of patients with carpal tunnel syndrome referred to surgeons: are nonoperative interventions effectively utilised?. Postgrad Med J. 2007 July; 83(981): 498-501.

22. Demirci S, Kutluhan S, Koyuncuoglu HR, et al. Comparison of open carpal tunnel release and local steroid treatment outcomes in idiopathic carpal tunnel syndrome. Rheumatol Int 2002 May;22(1):33-7.

23. Dammers JH, Veering MM, Vermeulen M. Injection with methylprednisolone proximal to the carpal tunnel: randomised double blind trial. BMJ 1999; 319 (7214): 884-886.

24. Badarny S, Rawashdeh H, Meer J, Abed S, Habib G. Repeated electrophysiologic studies in patients with carpal tunnel syndrome following local corticosteroid injection using a novel approach. Ir Med Assoc J 2011; 13(1):25-8.

25. Marshall S, Tardif G, Ashworth N. Local corticosteroid injection for carpal tunnel syndrome. Cochrane Database Syst Rev 2007 Apr 18;(2): pub med. CD001554. 